\title{
INFORMATION ABOUT COST OF GOODS PRODUCED AND ITS USEFULNESS FOR PRODUCTION ENGINEERS - A CASE OF SME
}

\author{
Ewa Wanda MARUSZEWSKA, Marzena STROJEK-FILUS \\ University of Economics in Katowice \\ Zita DRÁBKOVÁ \\ University of South Bohemia in Ceske Budejovice
}

\begin{abstract}
:
The article stresses the consequences of simplifications implemented in the measurement process of goods produced that are of crucial importance to production engineers in SME. The authors show the variety of possibilities that might be used by financial employees together with probable outputs in terms of valuation distortions. Using the case study the authors emphasis the importance of close cooperation of production engineers with finance professionals as outputs of finance departments consist an important input for decision-making process of production managers. Furthermore, demonstrated deficiencies in terms of methods applicable in financial reporting for measurement of the value of goods produced indicate the need for incorporation more financial and non-financial data in the process of judgments about the final cost of goods produced as simplifications applied in SME distort financial information provided to production engineers.
\end{abstract}

Key words: accounting, cost accounting, methods of cost calculations, cost management in SME, production engineering

\section{INTRODUCTION}

In the globalization era, contemporary market economy requires modern companies to be flexible within the implemented price policy and with a certain level of product quality derived from customers' demands. On the other hand, decisions on pricing depend upon detailed information referring to the cost of goods produced. Many small and medium sized companies use traditional cost methods in order to fulfill financial reports requirements as well as to provide managerial information. Small entities cannot use the same resource input in managing cost because of the lack of proper software and because most of management cost methods and tools were developed for enterprises with enough resources. The above raises an issue concerning the exact methodology of the measurement of cost of goods manufactured $[7,9,10]$. The issue is of crucial importance in the case of multi-assortment production [11] and in a situation of intercompany inventory exchanges when possible simplifications in the allocation of indirect costs are implemented [15]. Each simplification of indirect cost allocation leads to distortion and low-quality information provided by accountants to managers who make decisions regarding production management [2]. Moreover, the misrepresentation refers not only to the cost of goods that are of crucial interest, but it misstates all the other cost items [1]. In other words, the decision about cost allocation to product $X$ influences all the other products in the company (and/or segment of products, assortment of products).

The aim of the article is to present simplifications most often used by SME when deciding about indirect cost allo- cation together with the analysis of their consequences in the terms of information content. Authors state that cost allocation simplifications are accurate for cost measurement in SME and therefore managers shall be aware of possible distortions. Proper management of costs is a crucial determinant of whether a business succeeds or not thus expense management is central task especially in SME where creating pivotal technology, organizing production and managerial decisions are often in the hands of one employee. Furthermore, accountants calculate cost of goods manufactured not always with the awareness of the importance of whom and for what purpose uses financial data prepared by employees working in finance (accounting) departments.

\section{COST OF GOODS PRODUCED - LAW VERSUS PRACTICE OF SME}

Small and medium-sized enterprises comprise of many different business entities in terms of goods produced (services rendered), types of ownership or scope and geographical region of business activities. The above results in different types of finance management, including investment policy and management of production processes together with administration and controlling of assets. Moreover, contemporary market economy requires modern companies to be flexible in order to reply to industry (or sector) demands [3]. Very often, the answer to market needs ends up in lowering of cost of goods produced. Confronting the pressure from current high cost requires improving financial cost management on operational and strategic level as well. 
Both current operations and development of SME stand in need for financial decisions regarding production engineering. Although decisions based on financial data are not the core issue in production engineering, it is impossible to put financial issues on side and omit its influence on decision-making process. Because of the above, authors stress that engineers should be aware of simplifications implemented in the process of financial data preparation that is done in financial departments. Simplifications might lead to underestimation of cost of goods produced due to limited stipulations concerning specified categories of indirect costs or might end up with overestimation of cost of completed goods, i.e. in a case of unused production capacity.

According to international and Polish accounting regulations [12], entities are obliged to measure cost of goods produced including all direct and indirect costs. The definition states clearly that manufacturing (production) cost comprises any costs directly relating to that product and a justified portion of costs indirectly relating to the manufacturing process. Direct costs encompass the value of direct materials consumed in the production process together with other costs incurred in order to bring a product to the form and place in which it is found on the measurement date. A justified portion of indirect costs referring to the production process comprises all variable indirect production costs as well as a portion of fixed indirect production costs. The portion of indirect production costs derives from the calculation of the level of costs incurred during the normal operating cycle that is appropriate (planned) for the entity. Following, the normal operating cycle is considered to be the average expected production volume in typical conditions of a business entity. In other words, the operating cycle derives from production planning decided by production managers. The decision process regarding an average volume of production, usage of assets available (i.e. machinery, materials, and employees), planned overhauls etc. is an element of production engineering. This is the first moment when finance and production departments, represented by employees with completely different knowledge, should cooperate closely in order to provide detailed and reliable data for the measurement of cost of goods produced. Often SME are characterized by assumption taken by granted that all available resources are used during normal operating cycle. In other words, financial employees have no knowledge about assets that were not used in production process during a certain period. This happens because usually no standards exist regarding normal operating cycle in SME and production management does not calculate economic resources that are available but not used in a certain extend of time. On the other hand it should be noted that financial (accounting) employees do not ask for it as management reporting (inter alia about cost of goods produced) is based on financial reporting regulated by accounting law. It is worth to stress that there is no legal obligation that the cost of goods produced for managerial purposes equals the cost of goods produced disclosed in financial reports presented to owners, fiscal agencies, banks etc. This simplification often exists in SME as it requires performance of one set of calculations instead of two different measurement procedures. As finance departments are primarily interested in formulating of financial reporting policy, the decision about the usage of one set of calculations for managerial and financial reporting is made within accounting departments. The described simplification creates considerable discrepancies between the economic phenomenon that should be reflected by financial data provided to the management and the information purporting to represent this economic phenomenon that is delivered to employees making decisions regarding production processes among others. As a result the cost of goods produced will be overestimated as per unit and as a total amount, too.

The second simplification that might influence managerial decisions arises from the distribution of costs between finished and non-finished products. Accounting regulations require division of goods produced between finished products, semi-finished and non-finished goods. Measurement of all three categories of products is based on the same types of costs allocated in a production process. The most important decision, which influence the quality of data provided for managerial decision-making, applies to two underlying accounting assumptions. The first applies to process wastage, while the second refers to the categories of costs encompassed in a valuation of non-finished and semifinished products. In SME, it is a normal practice that nonfinished products are not valued on the basis on standard cost encompassing inter alia process wastage. The other simplification relates to list of categories of costs entailed into the measurement of non-finished goods excluding indirect costs or some categories of direct costs. Valuation based on raw materials and direct wages only seems to be a standard solution offered by ERP systems for SME. At the same time, most of direct costs fluctuate violently on a dayto-day basis while indirect costs encompass fixed costs at large. Simplifications resulting in lowering of cost of nonfinished and semi-finished products conclude in overestimation of finished products primarily due to the need for allocation of indirect fixed costs for finished products. It is worth mentioning that accounting regulations allow to withdraw from the measurement of non-finished goods and allocate all direct and indirect costs for finished goods. Although the decision to apply the above policy is legally correct and meets the definition of faithful representation in financial reports, it seems inappropriate when discussing the information usefulness for engineers deciding about the production processes.

Decision to exclude certain categories of costs from measurement process might apply to finished products as well. In this case, the valuation of products is underestimated while the expenses influencing profit (loss) directly are overestimated. The crucial issue in this simplification refers to the allocation of the costs eliminated from product measurement process. Several solutions can be observed in this case. In the first approach the decision to expense them to profit and loss account is made. It results in lowering the profitability despite of the fact whether the products were sold or not. The second approach combines indirect costs with those direct costs that were omitted in the valuation process. In this solution, the decision whether to expense the costs directly (in the period of incurrence) or whether to link their allocation to the number of products sold influence the final managerial data obtained from finance departments. Both solutions bring about underestimating of manufactured goods and influence the profitability of the goods sold.

Similar situation might happen when standard costs are used and allocation of deviations from those standards is not controlled on a period-to-period basis. Changes in production volume (represented by raw materials used, wages, volume of goods produced, etc.) designate the amounts of 
costs allocated to contractual cost centers. The above simplification, often used in ERP systems for SME, might produce over- and underestimated amounts assigned to finished and non-finished goods. It also raises a question of cost drivers designating the amounts of cost allocated for products and expensed directly in the period. Usually, the costs for allocation procedure consist of items that are dissimilar in nature and that fluctuate in a different manner. In $\mathrm{SME}$, on a regular basis, this colorful bulk of costs is allocated using only one cost driver that does not reflect the cost behavior. Although allocating all indirect costs the entity avoids underestimation of the cost of all manufactured goods, it does not guarantee precise valuation for production engineer whose aim is to differentiate products in terms of efficiency and economics.

The above description of the simplification most often used in SME in the measurement process of finished, nonfinished and semi-finished products reveals the problems that production engineers may face. Simplifications in measurement techniques are the right things to do but users of financial data should be aware of their consequences in terms of reliability and relevance particularly.

\section{A CASE STUDY OF INDIRECT COST ALLOCATION}

This case focuses on several management and calculating issues facing contemporary SME. The major issue is a managing value of the information provided by finance department to managers dealing with production processes. Table 1 presents information about costs incurred in a production process run in one workshop of an entity that produces two different products: product $A$ and product $B$. Although products differ in terms of physical and chemical characteristics, some fixed assets and materials used in the production processes are the same, while others are completely different. Moreover, as this case study deals with $\mathrm{SME}$, the same employees (including workshop manager) are engaged in both production processes. The above raises certain issues in the calculation of cost of goods produced. It can be observed from Table 1 that there are direct costs that can be precisely allocated to each product, but the majority of costs (58\%) comprise of indirect costs that cannot be allocated to each product definitely without uncertainty.

Based on accounting theory and according to law regulations, SME have many different possibilities regarding the measurement of cost of goods produced. Table 2 presents first set of possibilities based on the total cost formula that encompasses all costs incurred in a production process into the value of goods produced: direct costs and indirect costs in spite of whether they are fixed or variable costs. Although all kinds of costs are included in the measurement process there are several possibilities of performance of the valuation procedure. The difference between six solutions presented in Table 2 is due to various indirect cost allocation schemes.

As indirect costs represent one cost center that is shared by two different production processes, the associated expenses are to be assigned to each product consuming indirect materials, services etc. The core issue of indirect cost allocation system is a key used in order to perform the allocation. Although indirect costs comprise of different kinds of costs that change in dissimilar ways in a production processes, SME usually decide to use one allocation key for all indirect cost. From the financial reporting perspective such a solution is appropriate but when it comes to managing value of the information about cost of goods produced, engineers might not receive the relevant information. As production engineering consists primarily planning, performance evaluation, and decision-making in reference to the budgets approved, a sound understanding of the varied and complex ramifications of costs calculations is essential to adequate use of financial data resulting in good decisions.

Table 1

Financial data about direct and indirect costs incurred in the production of product $A$ and product $B$

\begin{tabular}{lccc}
\hline & Direct costs information & & Total \\
\hline & Product A & Product B & 18500 \\
Materials & 4200 & 14300 & 14700 \\
Direct labor costs & 8100 & 6600 & 2250 \\
Services & 200 & 2050 & 1120 \\
Other direct costs & 300 & 820 & $\mathbf{3 6 5 7 0}$
\end{tabular}

Depreciation

Building running costs

Energy costs

Indirect materials

Health \& safety

Indirect labor costs

Other indirect costs

Indirect costs - total

Total costs
Indirect costs information

$\begin{array}{cc}11050 & 11050 \\ 10050 & 10050 \\ 2015 & 2015 \\ 10900 & 10900 \\ 7600 & 7600 \\ 5100 & 5100 \\ 3800 & 3800 \\ \mathbf{5 0 1 5 0} & \mathbf{5 0 1 5 0} \\ \mathbf{8 7 0 8 5} & \mathbf{8 7 0 8 5}\end{array}$

Number of items produced

Number of working hours

Workshop metric usage
Additional information 
Table 2 Value of cost of goods produced in several indirect cost allocation schemes

\begin{tabular}{|c|c|c|c|}
\hline Cost items & Product $\mathrm{A}$ & Product B & Total \\
\hline \multicolumn{4}{|c|}{ Solution 1: total cost formula, allocation key based on direct materials used } \\
\hline Direct costs & 12800 & 23770 & 36570 \\
\hline Indirect costs & 11468 & 39047 & 50515 \\
\hline Cost of goods produced & 24268 & 62817 & 87085 \\
\hline \multicolumn{4}{|c|}{ Solution 2: total cost formula, allocation key based on direct labor costs } \\
\hline Direct costs & 12800 & 23770 & 36570 \\
\hline Other indirect costs & 27835 & 22680 & 50515 \\
\hline Cost of goods produced & 40635 & 46450 & 87085 \\
\hline \multicolumn{4}{|c|}{ Solution 3: total cost formula, allocation key based on direct materials used + direct labor costs } \\
\hline Direct costs & 12800 & 23770 & 36570 \\
\hline Other indirect costs & 18715 & 31800 & 50515 \\
\hline Cost of goods produced & 31514 & 55570 & 87085 \\
\hline \multicolumn{4}{|c|}{ Solution 4: total cost formula, allocation key based on total direct costs } \\
\hline Direct costs & 12800 & 23770 & 36570 \\
\hline Other indirect costs & 17681 & 32834 & 50515 \\
\hline Cost of goods produced & 30481 & 56604 & 87085 \\
\hline \multicolumn{4}{|c|}{ Solution 5: total cost formula, allocation key based on number of working hours } \\
\hline Direct costs & 12800 & 23770 & 36570 \\
\hline Other indirect costs & 11355 & 39160 & 50515 \\
\hline Cost of goods produced & 24155 & 62930 & 87085 \\
\hline \multicolumn{4}{|c|}{ Solution 6: total cost formula, allocation key based on workshop metric usage } \\
\hline Direct costs & 12800 & 23770 & 36570 \\
\hline Other indirect costs & 35807 & 14708 & 50515 \\
\hline Cost of goods produced & 48607 & 38478 & 87085 \\
\hline
\end{tabular}

Table 3

Value of cost of goods produced when some elements of costs are omitted

\begin{tabular}{lccc}
\hline \multicolumn{1}{c}{ Cost items } & Product A & Product B & Total \\
\hline Solution 7: schedule of costs includes direct costs & 12800 & 23770 & 36570 \\
Direct costs & $\mathbf{1 2 8 0 0}$ & $\mathbf{2 3 7 7 0}$ & $\mathbf{3 6 5 7 0}$ \\
$\begin{array}{l}\text { Cost of goods produced } \\
\text { Solution 8: schedule of costs includes direct materials + labor }\end{array}$ & 12300 & 20900 & 33100 \\
$\begin{array}{l}\text { Elements of direct costs } \\
\text { Cost of goods produced }\end{array}$ & $\mathbf{1 2 3 0 0}$ & $\mathbf{2 0 9 0 0}$ & $\mathbf{3 3 1 0 0}$ \\
Solution 9: schedule of costs includes direct materials & 4200 & 14300 & 18500 \\
Direct costs & $\mathbf{4 2 0 0}$ & $\mathbf{1 4 3 0 0}$ & $\mathbf{1 8 5 0 0}$ \\
Cost of goods produced & & & \\
\hline
\end{tabular}

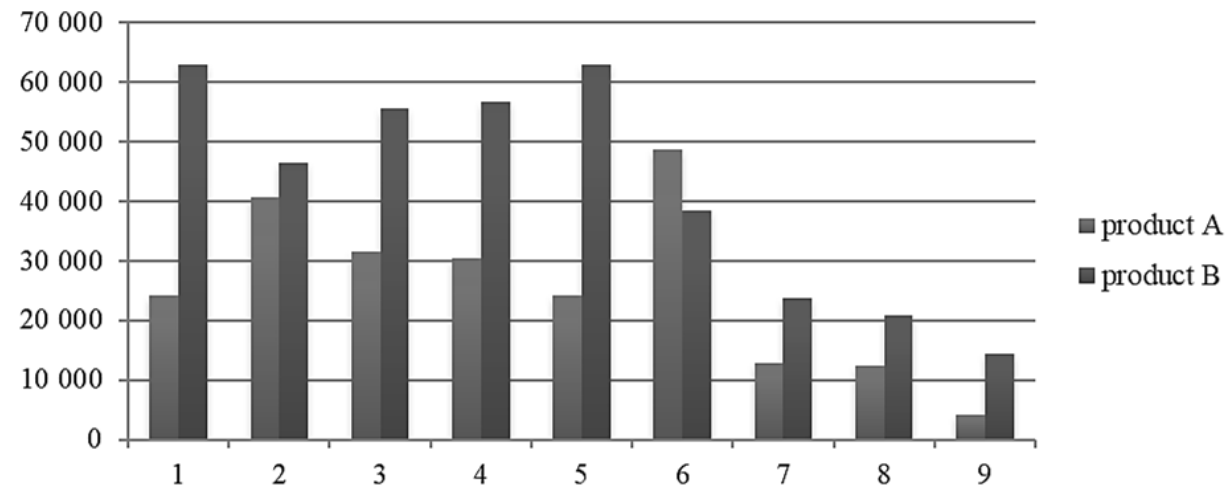

Fig. 1 Variances in cost of goods produced valuations

Based on the nine solutions presented in Tables 1 and 2, Fig. 1 summarizes the valuation outcomes.

It can be seen that the discrepancies between chosen solutions are enormous. The maximum valuation of product $A$ exceeds more than ten times the lowest measure- ment of its cost. Item B measurement produces similar results. It is worth pointing out that all solutions are legally acceptable and they are just nine actions chosen by authors although the list of acceptable calculations is much longer. 


\section{DISCUSSION}

At present, no one who has responsibility for managing high technology products and processes will dispute the importance of controlling the costs of production. Costs create constant source of concern to production engineers when considering different technical options or assessing the cost impact of introducing changes to existing designs. On the other hand, costs are particularly to the fore for sales and finance departments in SME when establishing budgets, evaluating price proposals or calculating gross margin for each product. In other words, costs are fundamental tasks for many different groups of management employees in SME organizations. In most instances, cost of goods produced as an output of an algebraic exercise is not an end in itself but rather is an input to a decision making process. Thus, measurement of cost of goods produced is an attempt to capture production processes in a systematic way in order to tackle different aspects of coast behavior that can be used for prediction of future costs as well as in minimization of risk of overspends against budget. Cost measurement serves also as a basis for expert judgments whether the relation between technical aspects and the related costs has appropriate balance. Analysis of cost of goods produced done by production engineers goes beyond the above mentioned, because the information about the cost and its components and mutual dependence can also be applied to support the aim of achieving more costeffective results. Awareness of the related cost is a key factor in the choice of approaches and design solutions [6].

Whilst measurement of cost of goods produced and production cost assessment remain fundamentally important for production engineering. There are two broad aspects of understanding underpinnings of cost calculations: cost classification and cost behavior. Cost classification refers to the separation of costs into direct and indirect costs' categories. Cost behavior refers to the effect that manufacturing volume has on total costs. As production engineers are responsible for making the production process as efficient as possible, they achieve this by using various principles of engineering, technology, manufacturing, management science, and financial information as well. Because of the above, measurement of cost of goods produced is a vocation that has significant overlap with manufacturing and industrial engineering. Furthermore, reliable cost calculation requires superb knowledge of the entire manufacturing process from start to finish and thus depend upon close cooperation of finance employees with production engineers [5]. In addition, algorithm for cost measurement necessitates for updates and improvements whenever i.e. production process, product parameters or manufacture capabilities have changed.

In the case study presented in Tables 1-3 and on the Fig. 1 we look in particular at the data provided to engineers by finance departments in SME. The aim of the case study is to stress the need for detailed financial data, especially on product costs at the level of unit cost of finished as well as non-finished goods. As production engineering focuses primarily on manufacturing efficiency we emphasis the need for close cooperation between production engineers and employees working in finance departments. Understanding of the mutual needs and responsibilities will allow any party involved in measurement or usage of cost data in a decision-making process decide what elements are of crucial importance in a certain organizational settings. Accordingly, production manager will recognize essential determinants of costs of goods produced and consequences of simplifications applied in measurement process. It is natural for SME to use simplifications in the measurement procedures, but in this case it is of crucial importance that production engineer has thorough knowledge about cost behavior in terms of relations between cost determinants and amount of costs. When simplifications are implemented in the valuation process, the cost calculation provided by financial departments may not be sufficient data for decision-making regarding production engineering. Hence, production engineer has to be aware that faithful information in financial reporting does not mean reliable and useful information for production engineering, as financial reporting regulation does not imply only one possible solution with regards to the measurement of goods produced.

\section{CONCLUSIONS}

Production engineering focuses on manufacturing effectiveness discussing primarily the issue of cost drivers, time involved, existing production resources, quality, and human resources. Thus financial departments, especially in SME, should help (in financial dimension) in making proper post ante cost calculations as well as in estimates of upcoming manufacturing needs and help production managers to take the right decision regarding planning, direction and coordination of all manufacturing processes. Demonstrated deficiencies in terms of methods applicable in financial reporting for measurement of the value of goods produced indicate the need for incorporation more financial and nonfinancial data in the process of judgments about the final cost of goods produced as simplifications applied in the measurement process distort financial information provided to production engineers. Moreover, the simplifications put into use in the valuation of semi-finished goods and non-finished goods are also sensitive to valuation parameters of finished goods. The discussed issue gains even more interest in a situation of intercompany inventory exchange when transfer prices are the basis for relocation of goods between distinct entities or branches [4]. For the reason of internal relations between basic financial parameters used in the measurement process, the authors call for counterpart application of other performance indicators related to e.g. productive (effective/total) working hours devoted to overhead activities, required routine maintenance of equipment that are useful indicators of production efficiency, production processes that are independent of the recorded financial results. Independent indicators are not as critical when accounting system is highly reliable in managerial value terms, which requires accuracy of financial data together with low uncertainty about financial data. In case of $\mathrm{SME}$, when simplifications are applied, the increase in the confidence of the production engineer in the reasonableness of the numbers is strongly recommended. As complete end planning, direction and co-ordination of all the manufacturing processes are important responsibilities of production engineering, decision-making process should be based on different kind of cost information included in the schedule of cost: financial and non-financial. Our finding is in accordance within the previous literature searching for different cost allocation methods that are on demands for service by division managers $[8,13,14]$. On that account, the article calls for transparency in schedule of cost of goods manufactured as it can increase the reliability in terms of production engineering needs. 


\section{REFERENCES}

[1] W. Caputa, M. Strojek-Filus, "Manufacturing Cost of Product and Customer Value on the Basis of Beer Industry In Poland", Journal of Business Management and Corporate Affairs, vol. 2, no 2, pp. 30-40, 2013.

[2] G. Cokins, S. Capusneanu, "Cost drivers. Evolution and benefits", Theoretical and Applied Economics, vol. 8, no 549, pp.7-16, 2011.

[3] S. Deevski, "Cost allocation methods for joint products and by-products", Economic Alternatives, vol. 1, pp. 64 $-70,2016$

[4] Public Discussion Draft, Additional Guidance on the attribution of profits to permanent establishment, OECD, 2016. https://www.oecd.org/tax/transferpricing/BEPS-discussion-draft-on-the-attribution-ofprofits-to-permanent-establishments.pdf.

[5] J. Du, W.D. Cook, L. Liang, J. Zhu, "Fixed costs and resource alloacation based on DEA cross-eficiency", European Journal of Operational Research, vol. 235, no 1, pp. 206-214, 2014.

[6] D. Greves, H. Joumier, "Cost engineering for costeffective space programmes", ESA Bulletin, pp. 71-75, August, 2003.

[7] Horngren Ch., Datar S., Foster G., Cost Accounting. A Managerial Emphasis, India, Prentice-Hall of India, 2007.

[8] H. Percevic, I. Drazic-Lutilsky, "Cost allocation Accounting Methods used in the Croatian Production Sector", South East European Journal of Economics \& Business, vol. 3, no 1, pp. 49-57, 2008.
[9] I. Sobańska, Ed., Rachunek kosztów i rachunkowość zarzq̨dcza, Warszawa, Poland, Wydawnictwo C.H. Beck, 2006.

[10] M. Strojek-Filus, "Variants of Determining of Manufacturing Cost of a Product in a Production Unit in the Light of Balance Sheet Law", Management Systems in Production Engineering, vol. 1, no 13, pp. 13-19, 2014. DOI 10.12914/MSPE-03-01-2014

[11] A. Sulik-Górecka, "Analiza rentowności klientów z wykorzystaniem rachunku kosztów działań jako narzędzia controllingu strategicznego", in Zarzq̨dzanie kosztami przedsiębiorstwa w warunkach ryzyka. Aspekty teoretyczne, J. Chluska, J. Rubik, Eds. Częstochowa, Poland, Wydawnictwo Wydziału Zarządzania Politechniki Częstochowskiej, 2014, pp. 127-134.

[12] The Accounting Act as of $29^{\text {th }}$ September 1994, consolidated text dated $19^{\text {th }}$ July 2016 , the Journal of Laws, item 1047

[13] M.J. Turner, A.T. Lord, "The usefulness of cost allocations: an experimental investigation", Academy of Accounting and Financial Studies Journal, vol. 12, no 2, pp. 27-45, 2008.

[14] A.O. Ujene, G.I. Idoro, I.A. Odesola, "Contractors perceptions of effects of project overhead costs on building project performance in South-South Nigeria", Civil Engineering Dimension, vol. 15, no 2, pp. 102-113, 2013.

[15] T. Veres, "Accounting aspects of pricing and transfer pricing", Annals of the University of Petrosani, vol. 11, no 2, pp. 289-296, 2011.

\section{Prof. UE Ewa Wanda Maruszewska, Ph.D.}

University of Economics in Katowice, Faculty of Finance and Insurance Department of Business Informatics and International Accounting ul. 1 Maja 50, 40-287 Katowice, POLAND e-mail: ewa.maruszewska@ue.katowice.pl

Prof. UE Marzena Strojek-Filus, Ph.D.

University of Economics in Katowice, Faculty of Finance and Insurance Department of Accounting

ul. 1 Maja 50, 40-287 Katowice, POLAND

e-mail: marzena.strojek@ue.katowice.pl

Ing. Zita Drábková, Ph.D.

University of South Bohemia in Ceske Budejovice

Faculty of Economics

Department of Accounting and Finance

Studentská 13, 37005. České Budějovice, CZECH REPUBLIC

e-mail: drabkova@ef.jcu.cz 